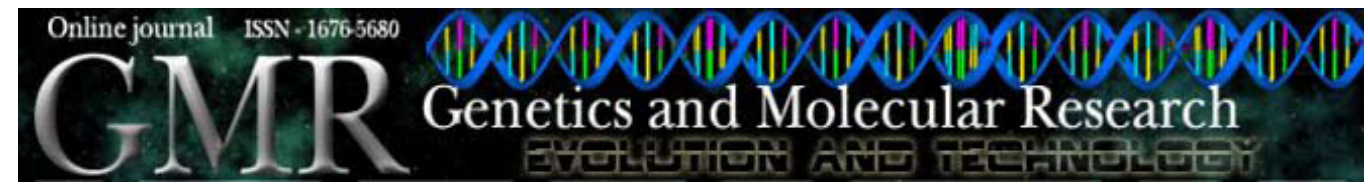

\title{
Karyotype description of two species of Hypostomus (Siluriformes, Loricariidae) of the Planalto da Bodoquena, Brazil
}

S.S. Cereali ${ }^{1}$, E. Pomini ${ }^{1}$, R. Rosa ${ }^{2}$, C.H. Zawadzki ${ }^{2}$, O. Froehlich ${ }^{1}$ and L. Giuliano-Caetano ${ }^{3}$

${ }^{1}$ Departamento de Biologia, Universidade Federal de Mato Grosso do Sul, CCBS, Campo Grande, MS, Brasil

${ }^{2}$ Departamento de Biologia, Universidade Estadual de Maringá, NUPELIA, Maringá, PR, Brasil

${ }^{3}$ Departamento de Biologia Geral, Universidade Estadual de Londrina, CCB, Londrina, PR, Brasil

Corresponding author: L. Giuliano-Caetano

E-mail: giuliano@uel.br

Genet. Mol. Res. 7 (3): 583-591 (2008)

Received April 22, 2008

Accepted June 17, 2008

Published July 1, 2008

\begin{abstract}
Hypostomus sp 3-Córrego Salobrinha NUP 4247 and $H y$ postomus sp 2-Rio Perdido NUP 4249, collected in the Planalto da Bodoquena, Paraguay River basin, Brazil, were characterized cytogenetically. Hypostomus sp 3-Córrego Salobrinha showed two modal numbers. This polymorphism consists of the presence of two extrachromosomes. It was not possible to define the diploid number in four specimens, where cell lineages had $2 n=83$ and $2 n=84$ chromosomes in one individual, and $2 n$ $=82,2 \mathrm{n}=83$ and $2 \mathrm{n}=84$ chromosomes in the others. These results reveal the existence of a genetic mosaic due to the occurrence of one or two extrachromosomes in this species. Hypostomus sp 2-Rio Perdido NUP 4249 showed a $2 \mathrm{n}=84, \mathrm{FN}=106$ with size heteromorphism in one pair of chromosomes stained with $\mathrm{AgNO}_{3}$. In both species, $\mathrm{C}$ banding showed a pattern of heterochromatin distribution with a few small bands in the centromeric and pericentromeric regions coinciding with chromomycin $\mathrm{A}_{3}$ staining. Until now, the major diploid number for the genus Hypostomus was $2 \mathrm{n}=80$, but the species studied here had chromosomes that in-
\end{abstract}


creased this number and the variation for this genus. Our results are also the first cytogenetic data on Hypostomus from the Paraguay River basin.

Key words: Hypostominae; Cytogenetics; Chromosomal polymorphism; Heterochromatin; B chromosome.

\section{INTRODUCTION}

Although Reis et al. (2003) consider the Loricariidae as the largest family of catfishes in the world, little is known about the karyotypic organization in this group (Artoni and Bertollo, 2001). Meanwhile, some studies provide some cytogenetics information for Loricariinae (Scavone and Júlio Jr., 1994; Giuliano-Caetano, 1998; Artoni and Bertollo, 2001), Hypoptopomatinae (Andreata et al., 1992, 1993, 1994), Hypostominae (Artoni et al., 1998, 1999; Artoni and Bertollo, 1996, 1999, 2001; Alves et al., 2006), Ancistrini (Lara, 1998; Artoni and Bertollo, 2001) and Neoplecostominae (Alves, 2000; Kavalco et al., 2005).

In spite of the small amount of information compared with the number of the species already described for Loricariidae, the available data demonstrate that this is a group of great interest for cytogenetic studies, due not only to the variation in chromosome number, $2 \mathrm{n}=$ 36 in Rineloricaria latirostris (Giuliano-Caetano, 1998) to $2 \mathrm{n}=96$ in Upsilodus sp (Kavalco et al., 2005), but also to the occurrence of many chromosomal rearrangements, suggesting a divergent karyotypic evolution (Artoni and Bertollo, 2001).

Hypostomus is considered to be one of the most diversified groups of Neotropical fishes, and is one of the most studied genera from a cytogenetic point of view, showing a variation in chromosome number from $2 \mathrm{n}=54$ in H. plecostomus (Muramoto et al., 1968, in Artoni and Bertollo, 2001) to $2 \mathrm{n}=80$ in Hypostomus sp E (Artoni and Bertollo, 1999).

The Planalto da Bodoquena is situated in the cities of Bonito and Bodoquena and in part of the cities of Jardim and Porto Murtinho, in Mato Grosso do Sul, Brazil. The main rivers are the Formoso, da Prata, Perdido, and Salobra (Boggiani, 1999), belonging to the Paraguay River basin. Although Willink et al. (2000) report the uniqueness of the ichthyofauna, with many endemic species, there are no cytogenetic data recorded for fishes of this region. Thus, the present cytogenetic results on the two species of Hypostomus from Planalto da Bodoquena are the first data from its ichthyofauna and the first on Hypostomus from the Paraguay River basin.

\section{MATERIAL AND METHODS}

Both species studied are new to science, and are deposited at the ichthyological collection of the Núcleo de Pesquisas em Limnologia, Ictiologia e Aquicultura (NUPELIA) at the Universidade Estadual de Maringá, under the catalog number NUP 4247 for Hypostomus sp 3-Córrego Salobrinha and NUP 4249 for Hypostomus sp 2-Rio Perdido. Thirteen specimens of Hypostomus sp 3-Córrego Salobrinha NUP 4247 were analyzed, including three males, four females and six young individuals, which were collected in the Salobra River located at $20^{\circ} 41^{\prime} 34^{\prime \prime} \mathrm{S}$ and $56^{\circ} 44^{\prime}$ $25^{\prime \prime} \mathrm{W}$, and in the Salobrinha Stream at $20^{\circ} 41^{\prime} 07^{\prime \prime} \mathrm{S}$ and 56 46' 44"W. For analysis of Hypostomus sp 2-Rio Perdido NUP 4249, there were five specimens including four males and one female, collected in the Perdido River at $21^{\circ} 17^{\prime} 09^{\prime \prime} \mathrm{S}$ and $56^{\circ} 41^{\prime} 46^{\prime \prime} \mathrm{W}$. The rivers and stream cited above are located in the Planalto da Bodoquena, State of Mato Grosso do Sul (Figure 1). 


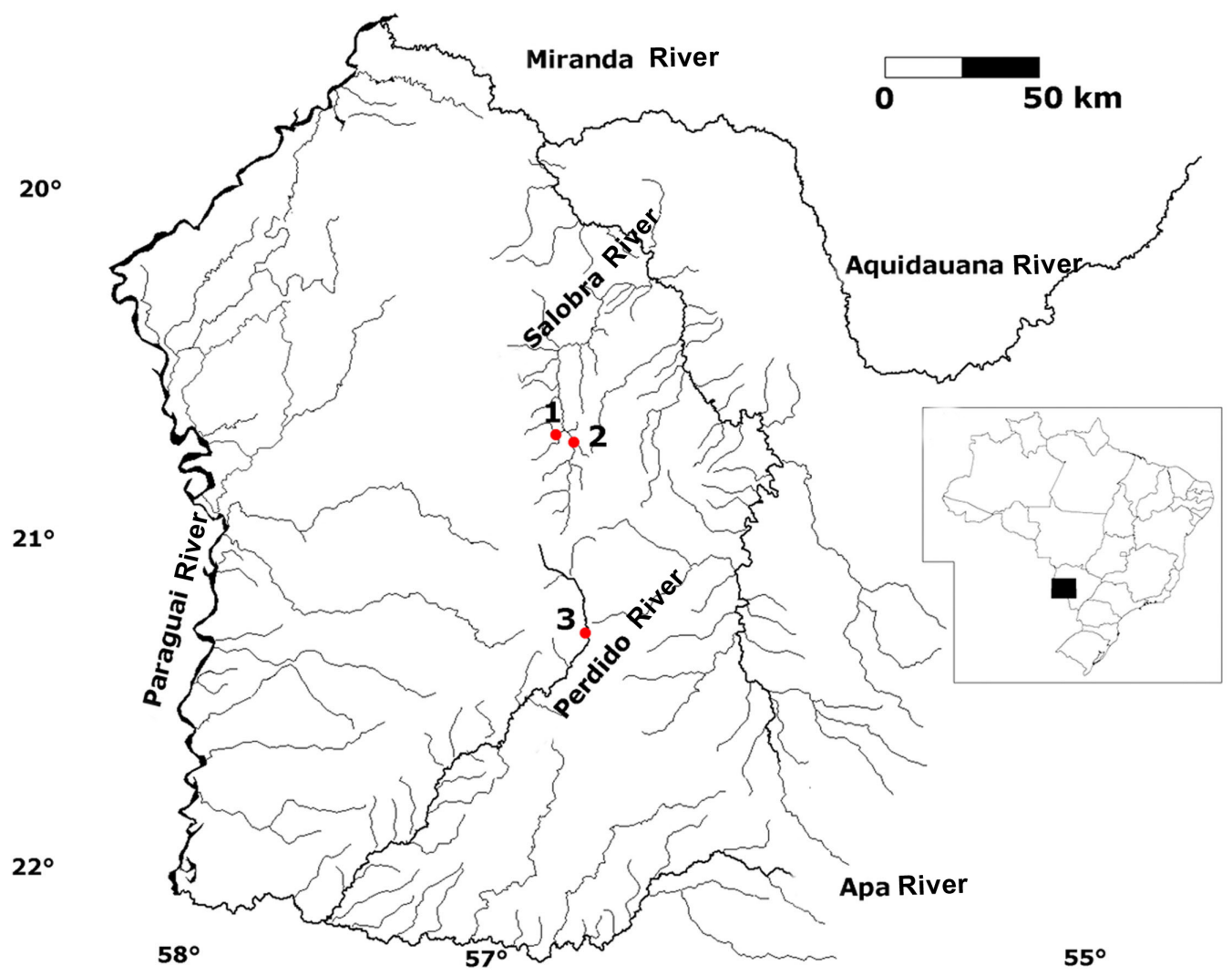

Figure 1. Localization of the area of study on the map of Brazil (inset) and localization of the collection points: Salobrinha Stream (1), Salobra River (2) and Perdido River (3).

For acquisition of mitotic metaphasic chromosomes, the conventional technique (Bertollo et al., 1978) or the alternative technique (Moreira Filho and Bertollo, 1990) was used. The chromosomes were classified into three groups: metacentrics (m), submetacentrics ( $\mathrm{sm}$ ), and subtelocentrics-acrocentrics (st-a), according to Levan et al. (1964), with modifications. $\mathrm{C}$ banding was used for determination of distribution pattern of heterochromatin (Sumner, 1972). Chromomycin $A_{3}$ / DAPI staining was according to Christian et al. (1998), with some modification.

\section{RESULTS}

A specimen of Hypostomus sp 3-Córrego Salobrinha NUP 4247 showed two distinct modal numbers, $2 \mathrm{n}=82$ and $2 \mathrm{n}=84$ (Figure 2) with variation in chromosome formula and fundamental number. One male and one female showed a $2 \mathrm{n}=82$, with a formula of $6 \mathrm{~m}+$ $12 \mathrm{sm}+64 \mathrm{st}-\mathrm{a}$, and $\mathrm{FN}=100$ (Figure 2A), while one male, one female and five juveniles showed a $2 \mathrm{n}=84$, with karyotype $6 \mathrm{~m}+12 \mathrm{sm}+66 \mathrm{st}-\mathrm{a}$ and $\mathrm{FN}=102$ (Figure $2 \mathrm{~B}$ ). In four 
specimens (one male, two females and one juvenile), it was not possible to define the diploid number, where two females and one juvenile had $2 \mathrm{n}=82$ (Figure 2A), $2 \mathrm{n}=84$ (Figure 2B) and $2 \mathrm{n}=83,6 \mathrm{~m}+12 \mathrm{sm}+65 \mathrm{st}-\mathrm{a}$, and $\mathrm{FN}=101$ (Figure $2 \mathrm{C}$ ), characterizing a case of genetic mosaicism due to extrachromosomes.

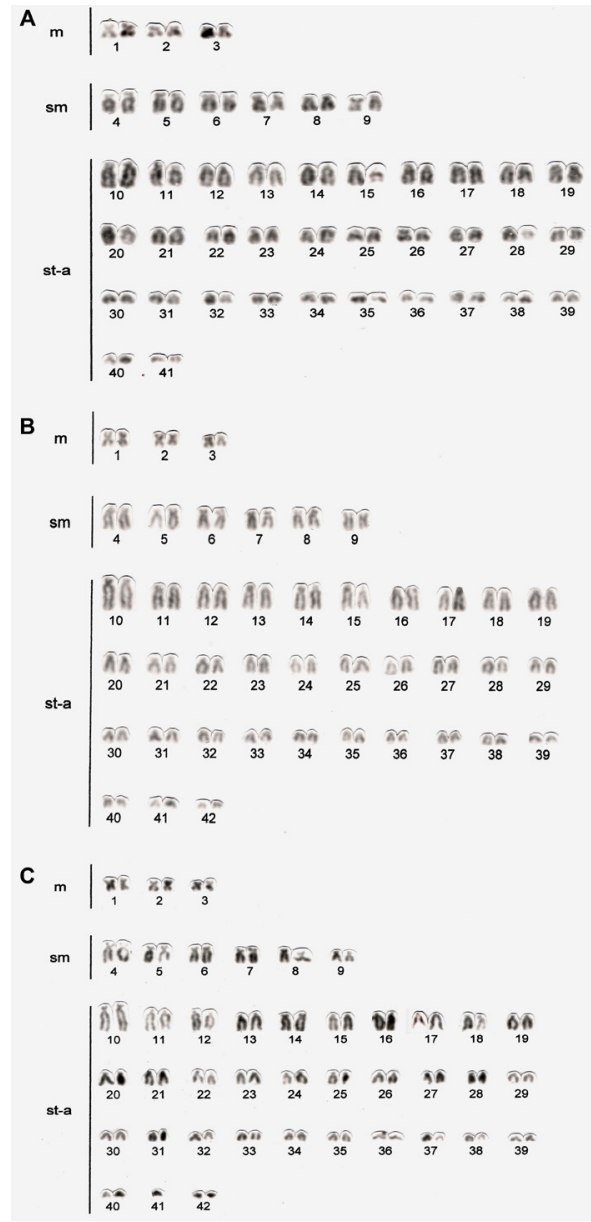

Figure 2. Cytotypes with $2 \mathrm{n}=82$ chromosomes (A), $2 \mathrm{n}=84$ chromosomes (B) and $2 \mathrm{n}=83$ chromosomes (C) Hypostomus sp 3-Córrego Salobrinha NUP 4247. $\mathrm{m}$ = metacentric; sm = submetacentric; st-a = subtelocentric-acrocentric.

The polymorphism encountered in Hypostomus sp 3-Córrego Salobrinha NUP 4247 may be due to the occurrence of one or two extrachromosomes, where the basic cytotype of the species is $2 \mathrm{n}=82$ chromosomes. There was no evidence of heterochromatic chromosomes, which suggests that these extrachromosomes would be euchromatic.

All specimens of Hypostomus sp 2-Rio Perdido NUP 4249 showed a modal diploid number of $2 n=84$, with karyotype formula of $6 m+16 s m+62 s t-a$, and $F N=106$ (Figure 3A). 
In four specimens, the secondary constriction in one of the homologs of pair 35 appeared very conspicuous after Giemsa staining (Figure 3A and B.1), $\mathrm{AgNO}_{3}$ impregnation(Figure 3B.2) and $\mathrm{CMA}_{3}$ staining, which also indicated size heteromorphism in the same pair (Figure 3B.3).

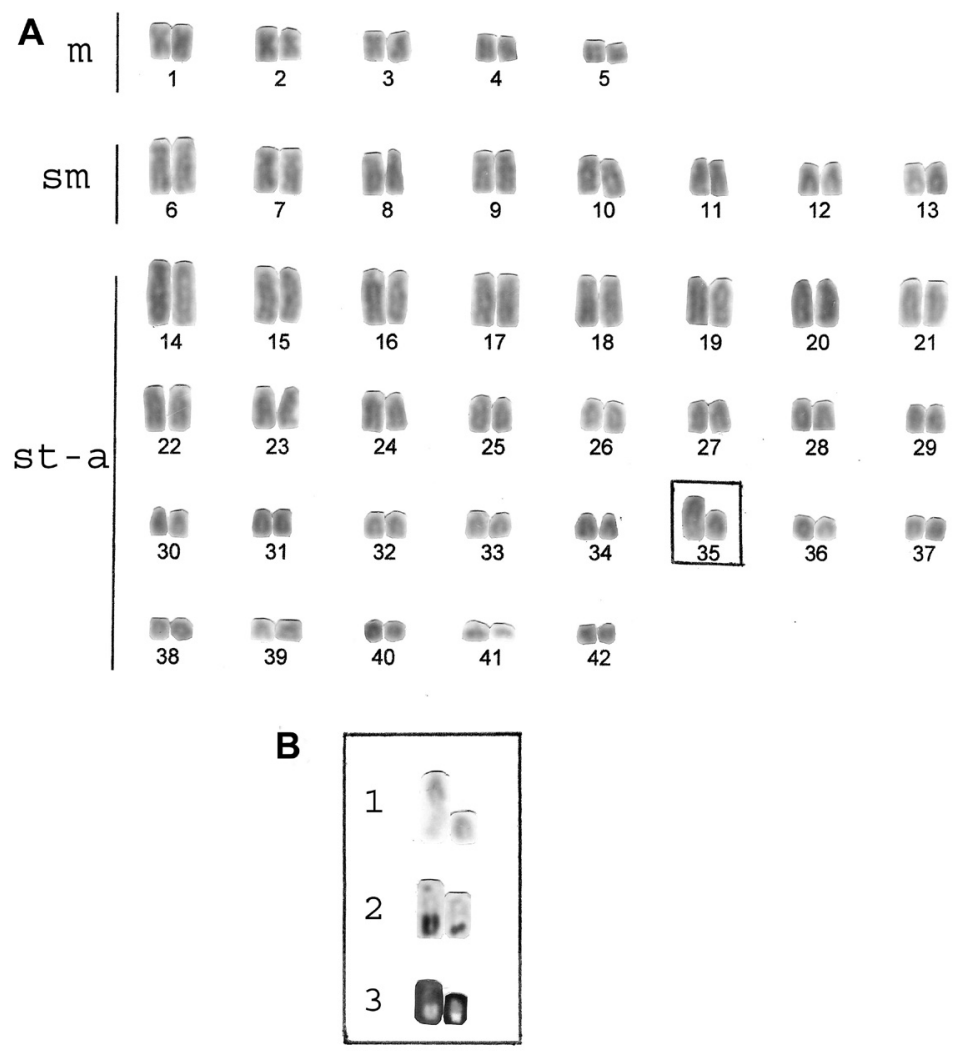

Figure 3. Karyotype of Hypostomus sp 2-Rio Perdido NUP 4249 with $2 \mathrm{n}=84$ chromosomes (A); secondary constriction observed in pair 35 (B): with Giemsa staining (B.1), impregnation with $\mathrm{AgNO}_{3}$ (B.2) and staining with fluorochrome $\mathrm{CMA}_{3}$ (B.3). $\mathrm{m}=$ metacentric; $\mathrm{sm}=$ submetacentric; st-a $=$ subtelocentric-acrocentric.

In the two species, banding showed evidence of a heterochromatin distribution pattern characterized by the presence of a few small bands in the pericentromeric region, and by the very evident block in the terminal position of the long arms of small acrocentric chromosomes (Figure 4A.a and B.a). Staining with $\mathrm{CMA}_{3}$ showed in Hypostomus sp 3-Córrego Salobrinha NUP 4247 at least two bands on the small acrocentric chromosomes, one of them being more evident than the other (Figure 4B.b). In Hypostomus sp 2-Rio Perdido NUP 4249, staining was very strong in the terminal region of the long arm of two small acrocentric chromosomes (Figure 4A.b). DAPI staining (Figure 4A.c and B.c) did not reveal any fluorescent bands in any of the two species studied. 

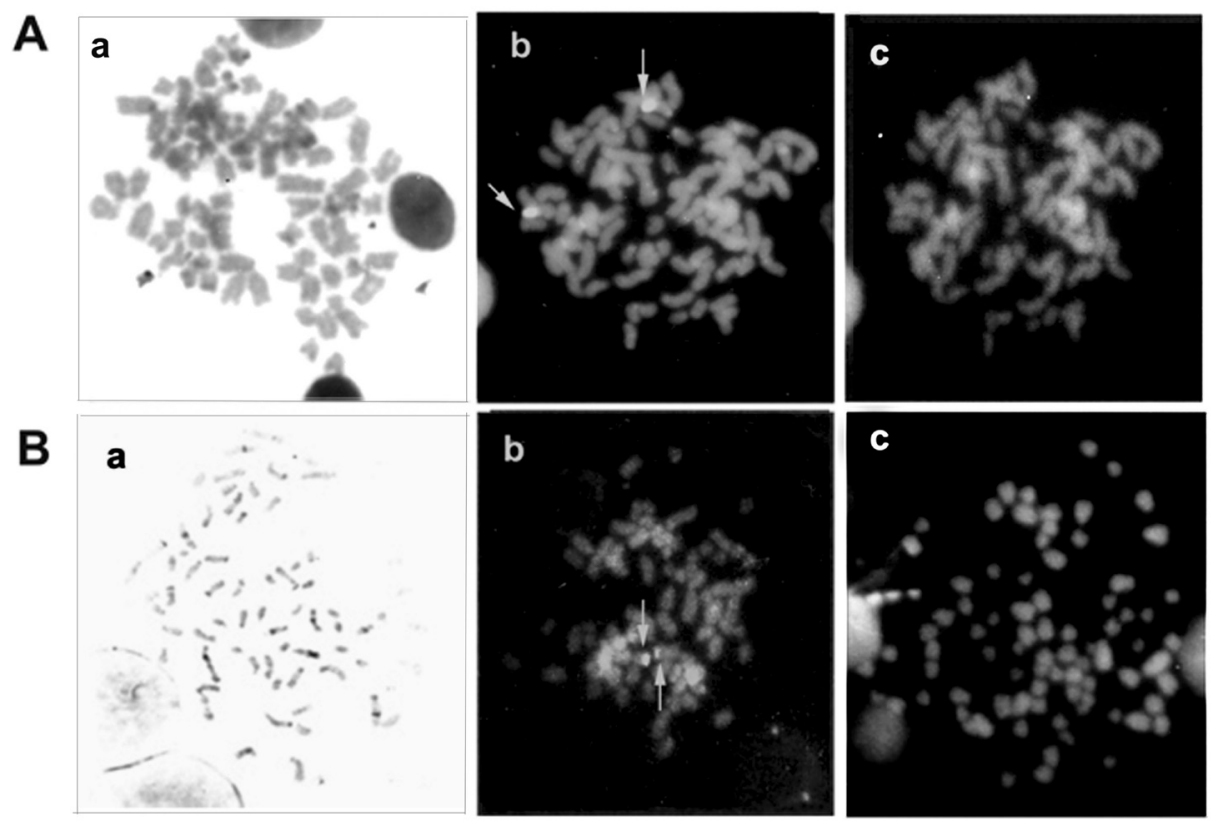

Figure 4. Metaphases showing pattern of distribution of heterochromatin in Hypostomus sp 2-Rio Perdido NUP 4249 (A) and Hypostomus sp 3-Córrego Salobrinha NUP 4247 (B) with C banding (a), with $\mathrm{CMA}_{3}$ staining (b) and DAPI staining (c).

\section{DISCUSSION}

The largest diploid number described, until now, for genus Hypostomus was $2 \mathrm{n}=80$ chromosomes, in Hypostomus sp E (Artoni and Bertollo, 1996). However, Hypostomus sp 3-Córrego Salobrinha NUP 4247 and Hypostomus sp 2-Rio Perdido NUP 4249 showed 2n = 82 and $2 n=84$ chromosomes, respectively, widening the range of variation for this genus.

In Hypostominae, the meta/submetacentric chromosomes are more frequent in species with lower diploid numbers, whereas the subtelo/acrocentric chromosomes prevail in species with higher diploid numbers (Artoni and Bertollo, 2001). This was evident in Hypostomus sp 3-Córrego Salobrinha NUP 4247 and Hypostomus sp 2-Rio Perdido NUP 4249 which were found to have many subtelo/acrocentric chromosomes, in contrast to Hypostomus cochliodon with $2 \mathrm{n}=64$ chromosomes which showed more meta/submetacentrics (Cereali, 2006).

In Hypostomus sp 3-Córrego Salobrinha NUP 4247, a chromosomal polymorphism with two cytotypes was observed, that is $2 \mathrm{n}=82$ and $2 \mathrm{n}=84$, due to the presence of extrachromosomes. These data are the first of such report for this genus. The difference between the two cytotypes is that there was one pair of small acrocentric chromosomes in $2 n=84$, but in cytotype $2 n=83$ the non-matched chromosome was one of the smallest acrocentrics of the complement. Because the chromosomes were not heterochromatic and due to the fact that they resembled the smaller sized acrocentrics, it was not possible to determine which were the extrachromosomes. Extrachromosomes non-heterochromatic as those found in Hypostomus sp 3-Córrego Salobrinha 
NUP 4247 were also described in Characidium cf. zebra (Venere et al., 1999), Steindachnerina insculpita (Oliveira and Foresti, 1993) and Rhamdia quelen (Moraes et al., 2007).

Extrachromosomes, supernumeraries and B chromosomes have been reported most frequently in Characiformes (Venere et al., 1999; Neo et al., 2000; Maistro et al., 2004). However, few cases are described in Siluriformes (Fenocchio and Bertollo, 1990; Dias and Foresti, 1993). B chromosomes are described in a few species of Loricariidae: Microlepdogaster leucofrenatus, from 1 to 2 Bs, in two locations (Andreata et al., 1993, 1994); Loricaria sp and L. prolixa, from 1 to 5 Bs (Scavone and Júlio Jr., 1994).

Hypostomus sp 3-Córrego Salobrinha NUP 4247 showed intraindividual numerical variation due to the presence of extrachromosomes with very similar frequency, which could be considered a case of chromosomal mosaicism. Borin and Martins-Santos (2000), described intraindividual numerical polymorphism in Thichomycterus davisi, where the variation was attributed to a probable post-zygotic nondisjunction of a metacentric chromosome of medium/ small size, followed by centric fission, producing a mosaic individual. Torres et al. (2002) use the expression "mosaicism" in the title of a study with fishes. The authors found an individual of Thichomycterus paolence suggesting the occurrence of aneuploidy due to post-zygotic nondisjunction during the first blastomere divisions.

According to Artoni and Bertollo $(1999,2001)$, there are two general patterns of heterochromatin distribution among the Loricariidae: 1 - few heterochromatin regions located in telomeric and/or centromeric regions, mostly associated with species with a smaller diploid number; 2 - many of these regions, besides heterochromatic segments in interstitial regions, mostly associated with species with a larger diploid number. The distribution of heterochromatin in Hypostomus sp 3-Córrego Salobrinha is consonant with the second group, while that in Hypostomus sp 2-Rio Perdido is close to the description of the first group.

Size heteromorphism among homologs of chromosomes stained with $\mathrm{AgNO}_{3}$ has been reported in species of Hypostomus by Artoni and Bertollo (1996), and also observed in Hypostomus sp 2-Rio Perdido NUP 4249.

In Loricariidae, regions rich in GC are described in Hypostomus (Artoni et al., 1998; Artoni and Bertollo, 1999; Kavalco et al., 2004) and Rineloricaria (Giuliano-Caetano, 1998) among others. AT-rich regions are rarely described in fishes. Although some species of Hypostomus studied by Artoni and Bertollo (1999) show fluorescent bands with DAPI staining, Hypostomus sp 3-Córrego Salobrinha NUP 4247 and Hypostomus sp 2-Rio Perdido NUP 4249 did not show such staining with DAPI, which indicates that AT-rich regions were very small or did not exist in our study.

Chromosomal polymorphisms generally do not cause any effect on phenotype, where they are normally detected only cytogenetically. Various examples found in nature show both structural and numerical chromosomal polymorphism (Dias and Giuliano Caetano, 2002). Beçak et al. (1966) showed three karyotypes for Lepomis cyanellus, $2 n=48,2 n=47$ and $2 n=46$. The standard karyotype for this species is $2 \mathrm{n}=48$, all acrocentric chromosomes. The karyotype $2 \mathrm{n}$ $=46$ presented $44 \mathrm{a}+2 \mathrm{~m}$, while $2 \mathrm{n}=47$ presented $46 \mathrm{a}$ and $1 \mathrm{~m}$. The autors concluded that this variation was due to a centric fusion between acrocentric chromosomes, with the formation of the metacentric chromosome. Intra-individual polymorphism was observed in the heterozygous specimens with the three karyotypes $(2 n=48,2 n=47,2 n=46)$ and somatic segregation favoring the reconstitution of homozygous cells was proposed to explain this fact.

The development of polymorphic populations is important as much for the population as the individual. In heterogeneous environments, a uniform population generally 
can exploit efficiently only some of the available ecological niches, while a polymorphic population is able to use more habitats when exploring the environment for those best suited (Ford, 1980). However, in the case of fishes, it is likely that periods of flood and drought, as well as climatic and physical chemistry alterations, have a greater influence on the occupation of niches than on the availability of habitats.

At the site where specimens of Hypostomus sp 2-Rio Perdido NUP 4249 were collected, the stretch of river is practically isolated by natural physical barriers. This is very unusual not only due to its physiognomy and the presence of only a few species (only nine) but also because among these, four were not found in any other place of the Planalto da Bodoquena and all were new to science, including the two species of Hypostosmus studied here. The Salobrinha Stream and Salobra River also have their own peculiarities, where Hypostomus sp 3-Córrego Salobrinha NUP 4247, in spite of being abundant there, is also a species not described previously.

These facts, combined with the characteristics of the region, make these populations of great interest. The continuity of cytogenetic studies of these and other species in the region is essential for a better comprehension of the evolutionary trends of the genus Hypostomus as a whole and especially in the Paraguay River basin.

\section{ACKNOWLEDGMENTS}

The authors are grateful to CAPES for financial support. NUPELIA provided logistical support. IBAMA gave permission for the research. We are also thankful to Dr. Ana Lucia Dias and Dr. Isabel Cristina Martins-Santos for suggestions to this reserach.

\section{REFERENCES}

Alves AL (2000). Análise da evolução dos gêneros da subfamília Hemipsilichthiinae (Ostariophysi, Siluriformes, Loricariidae) com base em caracteres cromossômicos e de DNA mitocondrial. Master's thesis, Universidade Estadual Paulista, Botucatu.

Alves AL, Oliveira C, Nirchio M, Granado A, et al. (2006). Karyotypic relationships among the tribes of Hypostominae (Siluriformes: Loricariidae) with description of XO sex chromosome system in a Neotropical fish species. Genetica 128: $1-9$

Andreata AA, Almeida-Toledo LF, Oliveira C and Toledo-Filho SA (1992). Chromosome studies in Hypoptopomatinae (Pisces, Siluriformes, Loricariidae): I. XX/XY sex chromosome heteromorphism in Pseudotocinclus tietensis. Cytologia 57: 369-372.

Andreata AA, do Almeida-Toledo L, Oliveira C and Toledo Filho SA (1993). Chromosome studies in Hypoptopomatinae (Pisces, Siluriformes, Loricariidae). II. ZZ/ZW sex-chromosome system, B chromosomes, and constitutive heterochromatin differentiation in Microlepidogaster leucofrenatus. Cytogenet. Cell Genet. 63: 215-220.

Andreata AA, Almeida-Toledo LF, Oliveira C and Toledo-Filho SA (1994). Cytogenetic studies on the subfamily Hypoptopomatinae (Pisces, Siluriformes, Loricariidae): III. Analysis of 7 species. Caryologia 47: 27-37.

Artoni RF and Bertollo LAC (1996). Cytogenetic studies on Hypostominae (Pisces, Siluriformes, Loricariidae). Considerations on karyotype evolution in the genus Hypostomus. Caryologia 49: 81-90.

Artoni RF and Bertollo LA (1999). Nature and distribution of constitutive heterochromatin in fishes, genus Hypostomus (Loricariidae). Genetica 106: 209-214.

Artoni RF and Bertollo LA (2001). Trends in the karyotype evolution of Loricariidae fish (Siluriformes). Hereditas 134: 201-210.

Artoni RF, Venere PC and Bertollo LAC (1998). A heteromorphic ZZ/ZW sex chromosome system in fish, genus Hypostomus (Loricariidae). Cytologia 63: 421-425.

Artoni RF, Molina WF, Bertollo LAC and Galetti PM Jr (1999). Heterochromatin analysis in the fish species Liposarcus anisitsi (Siluriformes) and Leporinus elongatus (Characiformes). Genet. Mol. Biol. 22: 39-44.

Becak W, Becak ML and Ohno S (1966). Intraindividual chromosomal polymorphism in green sunfish (Lepomis cyanellus) 
as evidence of somatic segregation. Cytogenetics 5: 313-320.

Bertollo LAC, Takahashi CS and Moreira-Filho O (1978). Cytotaxonomic considerations on Hoplias lacerdae (Pisces, Erythrinidae). Rev. Bras. Genet. I: 103-120.

Boggiani PC (1999). Por que Bonito é Bonito? - Geologia da Serra da Bodoquena. In: Nos Jardins Suspensos da Bodoquena - Guia para Idenitificação de Plantas Aquáticas de Bonito e Região (Scremin-Dias E, Pott VJ, Hora RC and Souza PR, eds.). Universidade Federal de Mato Grosso do Sul (UFMS), Campo Grande, 10-23.

Borin LA and Martins-Santos IC (2000). Intra-individual numerical chromosomal polymorphism in Trichomycterus davisi (Siluriformes, Trichomycteridae) from the Iguaçu River basin in Brazil. Genet. Mol. Biol. 23: 605-607.

Cereali SS (2006). Estudos citogenéticos de Loricariidae (Siluriformes) do Planalto da Bodoquena - Mato Grosso do Sul. Master's thesis, Universidade Estadual de Londrina, Londrina.

Christian A, McNiel E, Robinson J, Drabek R, et al. (1998). A versatile image analysis approach for simultaneous chromosome identification and localization of FISH probes. Cytogenet. Cell Genet. 82: 172-179.

Dias AL and Foresti F (1993). Cytogenetic studies on fishes of the family Pimelodidae (Siluroidei). Rev. Bras. Genet. 16: 585-600.

Dias AL and Giuliano-Caetano L (2002). Citogenética de alguns grupos de peixes da bacia do rio Tibagi. In: A bacia do rio Tibagi (Medri EM, Bianchini E, Shibatta OA and Pimenta JA, eds.). Universidade Estadual de Londrina, Londrina, 473-529.

Fenocchio AS and Bertollo LAC (1990). Supranumerary chromosomes in a Rhamdia hilarii population (Pisces, Pimelodidae). Genetica 81: 193-198.

Ford EB (1980). Genética e adaptação. Ed. da Universidade de São Paulo, São Paulo.

Giuliano-Caetano L (1998). Polimorfismo cromossômico Robertsoniano em populações de Rineloricaria latirostris (Pisces, Loricariinae). PhD thesis, Universidade Federal de São Carlos, São Paulo.

Kavalco KF, Pazza R, Bertollo LAC and Moreira-Filho O (2004). Heterochromatin characterization of four fish species of the family Loricariidae (Siluriformes). Hereditas 141: 237-242.

Kavalco KF, Pazza R, Bertollo LA and Moreira-Filho O (2005). Karyotypic diversity and evolution of Loricariidae (Pisces, Siluriformes). Heredity 94: 180-186.

Lara MCS (1998). Aspectos citogenéticos de quatro espécies de peixes da subfamília Ancistrinae (Siluriformes, Loricariidae) da bacia do rio Paraná. Master's thesis, Universidade Estadual do Maringá, Maringá.

Levan A, Fredga K and Sandberg AA (1964). Nomenclature for centromeric position on chromosomes. Hereditas 52: 201-220.

Maistro EL, Jesus CM, Oliveira O, Moreira-Filho O, et al. (2004). Cytogenetic analysis of A-, B-chromosomes and ZZ/ ZW sex chromosomes of Characidium gomesi (Teleostei, Characiformes, Crenuchidae). Cytologia 69: 181-186.

Moraes VP, Cereali SS, Froehlich O and Dias AL (2007). Cytogenetic characterization of Rhamdia quelen (Siluriformes, Heptapteridae) from the Bodoquena Plateau, Mato Grosso do Sul, Brazil. Genet. Mol. Res. 6: 627-633.

Moreira-Filho O and Bertollo LAC (1990). Uma técnica alternativa para preparações cromossômicas de peixes. III Simpósio de Citogenética Evolutiva e Aplicada de Peixes Neotropicais, Botucatu.

Neo DM, Filho OM and Camacho JP (2000). Altitudinal variation for B chromosome frequency in the characid fish Astyanax scabripinnis. Heredity 85 (Pt 2): 136-141.

Oliveira C and Foresti F (1993). Occurrence of supernumerary microchromosomes in Steindachnerina insculpta (Pisces, Characiformes, Curimatidae). Cytobios 76: 183-186.

Reis RE, Kullander SO and Ferraris CL Jr (2003). Check List of the Freshwater Fishes of South and Central America. EDIPUCRS, Porto Alegre.

Scavone MPD and Júlio HF Jr (1994). Cytogenetic analysis and probable supernumerary chromosomes of Loricaria prolixa and Loricaria sp. females (Loricariidae - Siluriformes) from the Paraná River basin. Rev. Ictiol. 2/3: 41-47.

Sumner AT (1972). A simple technique for demonstrating centromeric heterochromatin. Exp. Cell Res. 75: 304-306.

Torres RA, Foresti F and Oliveira C (2002). Occurrence of karyotypical mosaicism in Trichomycterus paolence (Teleostei, Trichomycteridae). Caryologia 55: 283-287.

Venere PC, Myiazawa CS and Galetti PM Jr (1999). New cases of supernumerary chromosomes in characiform fishes. Genet. Mol. Res. 22: 345-349.

Willink PW, Froehlich O, Machado-Alisson A, Menezes NA, et al. (2000). Diversidade, Distribuição, e Hábitats Críticos dos Peixes dos Rios: Negro, Negrinho, Taboco, Taquari e Miranda, e sua Importância para Conservação e Desenvolvimento Sustentável do Pantanal, Mato Grosso do Sul, Brasil. In: Uma Avaliação Biológica dos Ecossistemas Aquáticos do Pantanal, Mato Grosso do Sul, Brasil (Willink PW, Chernoff B, Alonso L, Montambault JR, et al., eds.). Conservation International, Washington, 63-81. 